GRASAS Y ACEITES 66 (1)

January-March 2015, e059

ISSN-L: 0017-3495

doi: http://dx.doi.org/10.3989/gya.0709142

\title{
Physicochemical and sensory properties of Celta dry-ripened "salchichón" as affected by fat content
}

\author{
S. Fonseca, M. Gómez, R. Domínguez, and J.M. Lorenzo ${ }^{\bowtie}$ \\ Centro Tecnológico de la Carne de Galicia, Rúa Galicia N 4, Parque Tecnológico de Galicia, San Cibrao das Viñas, 32900 Ourense, Spain \\ ${ }^{\square}$ Corresponding author: jmlorenzo@ceteca.net
}

Submitted: 01 July 2014; Accepted: 22 September 2014

SUMMARY: This work studies the effect of fat content on the main characteristics of a traditional, Spanish dry-ripened sausage called "salchichón" from the Celta pig breed manufactured with 10, 20 and 30\% back fat. Physicochemical properties, color, texture and free fatty acid profile were evaluated throughout the process after $0,7,21,35$ and 49 days of ripening, while the study of the volatile compound profile and the sensory evaluation were only performed on the final products. In general, most of the studied physicochemical, color and textural parameters were significantly $(P<0.05)$ affected by fat levels. Lipolytic reactions were also enhanced with increasing fat levels leading to a higher free fatty acid release. Sausages with $10 \%$ fat exhibited a higher content of volatile compounds, even though they did not show significant differences in flavor intensity. The sensory evaluation also reflected a preference for the texture of the sausages with $30 \%$ fat. This fact leads us to conclude that, although fat reduction would improve the nutritional quality of dry-ripened meat products, it can only be successful to a certain extent. Therefore, a formulation including $20 \%$ fat would be the most suitable for the elaboration of "salchichón" the from Celta pig breed.

KEYWORDS: Celta pig breed; Dry-ripened sausage; Fat content; Free fatty acids; Volatile compounds

RESUMEN: Influencia del contenido en grasa sobre las propiedades físico-químicas y sensoriales del "salchichón" Celta crudo-curado. En este trabajo se estudia el efecto del contenido en grasa sobre las principales características del "salchichón", un embutido crudo-curado tradicional español, elaborado con cerdo de raza Celta y con adición de 10, 20 y 30\% de grasa dorsal. Las propiedades físico-químicas, color, textura y perfil de ácidos grasos libres se evaluaron a lo largo del proceso tras $0,7,21,35$ y 49 días de maduración, mientras que el estudio del perfil de compuestos volátiles y la evaluación sensorial se llevó a cabo únicamente en los productos finales. En general, la mayoría de los parámetros físico-químicos, de color y textura estudiados se vieron significativamente $(P<0,05)$ afectados por el nivel de grasa. Las reacciones lipolíticas también resultaron favorecidas con altos niveles de grasa que dan lugar a una mayor liberación de ácidos grasos libres. Los embutidos con $10 \%$ de grasa mostraron un contenido más elevado en compuestos volátiles, a pesar de no haber mostrado diferencias significativas en la intensidad de flavor. La evaluación sensorial también reflejó una preferencia por la textura de los embutidos con 30\% de grasa. Este hecho nos lleva a concluir que, aunque la reducción de grasa mejoraría la calidad nutricional de los productos cárnicos crudo-curados, sería satisfactoria sólo si se lleva a cabo hasta cierto nivel. Por tanto, una formulación incluyendo $20 \%$ de grasa sería la más idónea para la elaboración de "salchichón" de cerdo de raza Celta.

PALABRAS CLAVE: Ácidos grasos libres; Cerdo de raza Celta; Compuestos volátiles; Contenido en grasa; Embutidos crudo-curados

Citation/Cómo citar este artículo: Fonseca S, Gómez M, Domínguez R, Lorenzo JM. 2015. Physicochemical and sensory properties of Celta dry-ripened "salchichón" as affected by fat content. Grasas Aceites 66 (1): e059. doi: http://dx.doi. org/10.3989/gya.0709142.

Copyright: (C) 2015 CSIC. This is an open-access article distributed under the terms of the Creative Commons Attribution-Non Commercial (by-nc) Spain 3.0 Licence. 


\section{INTRODUCTION}

The Celta pig is an autochthonous porcine breed raised traditionally in Galicia (northwest of Spain) and characterized by its rusticity. Because of their poor growth rate, carcass conformation and crossbreeding between local pigs and improved breeds, the Celta breed nearly became extinct during the second half of the 20th century (Franco et al., 2014). The aim of the recovery of the Celta pig breed is not only to obtain high-quality meat but also the contribution to the environmental preservation and the restoration of traditional practices. The carcasses, which are often very fatty, are used in the production of dry-cured meat products, which have a high value on the market and great quality (Lorenzo et al., 2012a). There is a growing demand for products derived from autochthonous breeds. This has permitted an increment in the census of the Celta pig, increasing from 623 animals in 2001 to 4882 at the end of 2012 (Carril et al., 2012).

"Salchichón" is a traditional Spanish dry-ripened sausage. The basic ingredients of "salchichón" are lean pork, pork back fat, salt and spices. Fat is the most influential component in these fermented sausages as it affects the texture and flavor of the final product. It is well known that fat acts as a reservoir for flavor compounds and contributes to product texture and juiciness, which determine the quality and acceptability of dry sausages (Muguerza et al., 2001; Lorenzo and Franco, 2012). Flavor formation in dry-ripened sausages is mainly related to lipolysis (Gandemer, 2002) through the generation of free fatty acids that are further subjected to lipid oxidation producing a large variety of volatile compounds (Lorenzo and Franco, 2012). Although the role of fat as a precursor of aromatic compounds is well known, there is controversy about how the fat content affects the volatile compounds and flavor. Olivares et al. (2011) noticed an increase in the volatile compounds in sausages with higher fat content, while Muguerza et al. (2003) concluded that sausages with a reduced fat content had a higher lipid oxidation and therefore had a higher content of volatile compounds.

Any fat reduction can affect the acceptability of the products. Some authors reported that lowfat fermented sausages become hard, have high weight loss and an unacceptable appearance (Liaros et al., 2009). Olivares et al. (2010) also concluded that low-fat sausages were less appreciated by consumers. However, a reduction in fat content would improve the nutritional quality of these sausages. In industrialized countries, high meat consumption contributes to a higher total and saturated fat as well as cholesterol intake than recommended. There are a number of experimental studies which show that fat-rich diets, in addition to causing obesity, are also directly related to the risk of colon cancer and cardiovascular diseases (Ferguson et al., 2004). Therefore, nowadays, increasing concerns about the potential health risk associated with the consumption of high-fat foods have led the food industry to develop new formulations or modify traditional foods to achieve a reduction in fat levels (Mendoza et al., 2001; Lorenzo et al., 2012).

The novelty of this work lies on the use of meat from the Celta pig breed for manufacturing "salchichón", as products from this breed were not subjected to many studies so far. Thus, the objective of this study was to decide the most appropriate formulation of this sausage by determining the influence of fat content on physicochemical, color and textural properties, as well as lipolysis and lipid oxidation, during the ripening period of a traditional Spanish dry-ripened sausage, "salchichón", made with fat and lean pork from the Celta pig breed. Also, the influence of fat level on the volatile compound profile and sensory quality of the final products was analyzed.

\section{MATERIALS AND METHODS}

\subsection{Sausage manufacture}

Three batches of "salchichón", each one with a different proportion of subcutaneous back fat $(10 \%, 20 \%$ and $30 \%)$, were manufactured in the pilot plant of the Meat Technology Center of Galicia (San Cibrao das Viñas, Ourense, Spain). The "Salchichón" formulation included lean, back fat and a supplement " 542 Salchichón" $\left(40 \mathrm{~g} \cdot \mathrm{kg}^{-1}\right)$ from Laboratorios Ceylamix (Valencia, Spain) composed, in unknown proportions, of sugar, salt, dextrin, spices (black and white pepper and nutmeg), milk protein, monosodium glutamate (E621), phosphates (E450i and E451i), sodium erythorbate (E316), potassium nitrate (E252) and coloring (E120). No starter culture was added. The lean pork and the back fat used in this elaboration were obtained from the Celta pig breed (Barcina line).

Lean and back fat were minced through a $10 \mathrm{~mm}$ diameter mincing plate at $2-3{ }^{\circ} \mathrm{C}$ and vacuum mixed with the rest of the ingredients. The mix was maintained at $3-5^{\circ} \mathrm{C}$ for $24 \mathrm{~h}$ and then was stuffed into collagen casings (Fibran, S.A., Girona, España, 55-60 $\mathrm{mm}$ diameter) so that the final weight of each sausage of around $550 \mathrm{~g}$. The sausages were fermented for 2 days at $20{ }^{\circ} \mathrm{C}$ and $80 \%$ relative humidity and then transferred into a drying-ripening chamber where they were kept for 47 more days at $11^{\circ} \mathrm{C}$ and $75 \%$ relative humidity. Five replicates from each batch were taken at day 0 , and after 7, 21, 35 and 49 days of ripening. After the color, $\mathrm{pH}$ and texture analysis, discarding the outer casing of each "salchichón", the samples were ground, vacuum packaged and frozen at $-30^{\circ} \mathrm{C}$ before subsequent analysis. For the sensory analysis, whole pieces of 
"salchichón" taken at the end of the ripening were vacuum packaged and stored at $4{ }^{\circ} \mathrm{C}$ until their evaluation.

\subsection{Physicochemical, color and textural properties}

The $\mathrm{pH}$ of samples was measured using a digital pH-meter (Thermo Orion $710 \mathrm{~A}+$, Cambridgeshire, UK) equipped with a penetration probe. Water activity was determined using a Fast-lab (Gbx, Romans sur Isére Cédex, France) water activity meter, previously calibrated with sodium chloride and potassium sulphate. The moisture content of the samples was determined by dehydration at $105^{\circ} \mathrm{C}$ until constant weight according to the ISO recommended standard 1442:1997. The thiobarbituric acid-reactive substances (TBARS) method was performed according to Vyncke (1975). TBARS values were calculated against a standard curve and expressed as $\mathrm{mg}$ of malonaldehyde (MA) per $\mathrm{kg}$ of sample. For each five replicates and after $15 \mathrm{~min}$ of blooming, color measurements were carried out in triplicate on the surface of sliced samples using a CM-600d colorimeter with an illuminant D65 and an aperture angle of $10^{\circ}$ (Minolta Chroma Meter Measuring Head, Osaka, Japan) in the CIELAB space (lightness, L*; redness, a*; yellowness, $\mathrm{b}^{*}$ ). A texture profile analysis (TPA) was made on "salchichón" slices of $1 \times 1 \times 2 \mathrm{~cm}$ (height $\times$ width $\times$ length) using a texture Analyzer (TA-XT.plus, Stable Micro Systems, GoUK) according to Lorenzo and Franco (2012).

\subsection{Free fatty acid content}

Total lipids were extracted from $5 \mathrm{~g}$ of each minced sausage sample, according to the Folch et al. (1957) procedure. Free fatty acids were separated from $50 \mathrm{mg}$ of the extracted lipids using aminopropyl $\left(\mathrm{NH}_{2}\right)$ mini-columns as described by García-Regueiro et al. (1994). This fraction was transesterified with a solution of boron trifluoride (14\%) in methanol, according to Carreau and Dubacq (1978) and the fatty acid methyl esters (FAMEs) were stored at $-80^{\circ} \mathrm{C}$ until their chromatographic analysis. Separation and quantification of FAMEs was determined following Lorenzo et al. (2012a) using a Supelco SPTM-2560 fused silica capillary column $(100 \mathrm{~m}, 0.25 \mathrm{~mm}$ i.d., $0.2 \mu \mathrm{m}$ film thickness, Supelco Inc., Bellafonte, PA, USA). Results for each free fatty acid were expressed as $\mathrm{mg} \cdot 100 \mathrm{~g}^{-1}$ dry matter and as relative percentage of total detected FAMES.

\subsection{Volatile compound profile}

The volatile compounds profile was studied in sausage samples taken at the end of the process after 49 days of ripening. The extraction of the volatile compounds was performed using solid-phase microextraction (SPME). An SPME device (Supelco, Bellefonte, PA, USA) containing a fused-silica fiber (10 mm length) coated with a $50 / 30 \mathrm{~mm}$ thickness of DVB/CAR/PDMS (divinylbenzene/carboxen/ polydimethylsiloxane) was used. Separation and quantification of the volatile compounds was determined following Lorenzo et al. (2013). Results for each volatile compound were expressed as AU (area units) $\times 10^{6} \cdot \mathrm{g}^{-1}$ dry matter.

\subsection{Sensory analysis}

The sensory panel evaluation was conducted with ten panelists selected from the staff of the Meat Technology Center of Galicia. Panellists were trained according to the methodology proposed by ISO regulations (ISO 8586:2012) during three months with the attributes and the scale to be used. Samples of each "salchichón" were individually three-digit coded and presented in unwrapped oblique slices approximately $5 \mathrm{~mm}$ thick on a small plate. The samples were evaluated by panelists in three sessions (three samples per session). During the sensory evaluation, the panelists were situated in a private cabinet illuminated with red light, according to ISO regulations (ISO 8589:2007). Water to clean their palates and remove residual flavors was used at the beginning of the session and between each sample. Nine sensory traits of "salchichón", grouped according to appearance (fat level and fat/ lean cohesiveness), odor (black pepper odor), taste (flavor intensity, acid taste and saltiness), and texture (hardness, juiciness and dryness) were assessed according to the methodology proposed by ISO regulations (ISO 3972:1991, ISO 11036:1994 and ISO 5496:2006). The intensity of every attribute was rated on a structured scale from 0 (sensation not perceived) to 9 (maximum of the sensation) and the results were expressed as the mean scores of each attribute given by all the panelists.

\subsection{Statistical analysis}

All statistical analyses were performed using the IBM SPSS Statistics 19 software (IBM, Armonk, NY, USA). A Duncan's test was performed to compare the mean values at a significance level of $P<0.05$. When the effect of days of ripening and fat level on physicochemical traits, free fatty acid content, volatile compound analysis and sensory evaluation were studied, a fixed effect of days of ripening and fat level were included in the model. The model used was:

$$
\mathrm{Yij}=\mu+\mathrm{Si}+\mathrm{Aj}+\varepsilon \mathrm{ij}
$$

Where: Yij is the observation of dependent variables, $\mu$ is the overall mean, $\mathrm{Si}$ is the effect of days of ripening, $\mathrm{Aj}$ is the effect of level of fat, and $\mathrm{cij}$ is the 
residual random error associated with the observation. Correlations between variables $(P<0.05)$ were determined by correlation analyses using Pearson's linear correlation coefficient with the above mentioned statistical software package.

\section{RESULTS AND DISCUSSION}

\subsection{Changes in physicochemical, color and textural properties during ripening}

The values corresponding to the physicochemical parameters (moisture, $\mathrm{a}_{\mathrm{w}}, \mathrm{pH}$, TBARS) throughout the ripening of "salchichón" from the Celta pig breed manufactured with different fat contents are shown in Fig. 1. At the end of the process, the fat content of "salchichón", as expected, was significantly different $(\mathrm{P}<0.05)$ among batches, with mean values of $23.21 \pm 6.24$ in the $10 \%$ fat batch, $31.24 \pm 6.86$ in the $20 \%$ fat batch and $37.98 \pm 1.51$ in the $30 \%$ fat batch, expressed as $\mathrm{g} \cdot 100 \mathrm{~g}^{-1}$ of dry matter (data not shown). Protein content was also different $(\mathrm{P}<0.01)$, presenting mean values of $22.01 \pm 0.83$ in the $10 \%$ fat batch, $20.96 \pm 0.91$ in the $20 \%$ fat batch and $18.28 \pm 1.04$ in the $20 \%$ fat batch, expressed as $\mathrm{g} \cdot 100 \mathrm{~g}^{-1}$ of dry matter (data not shown).
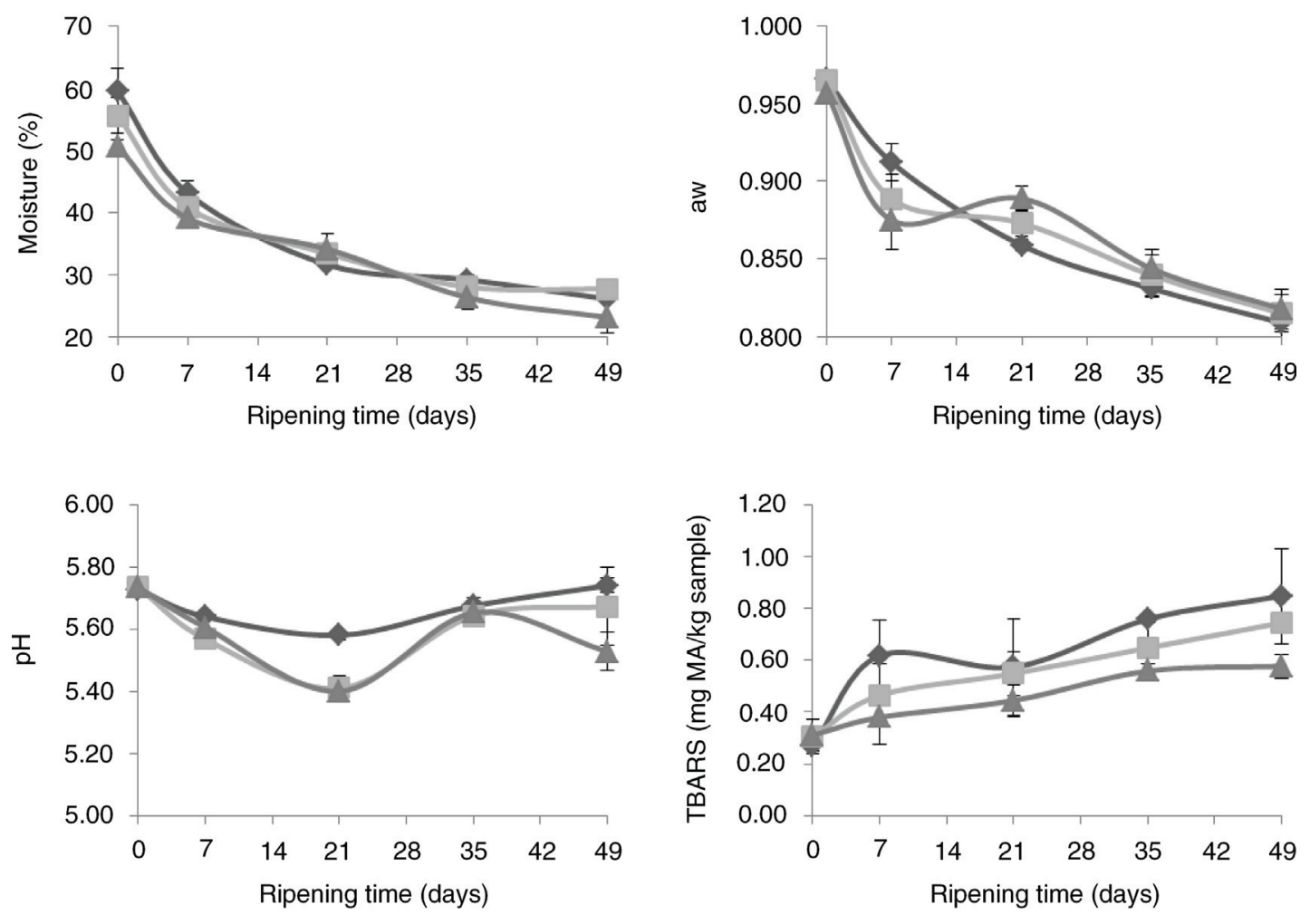

$\smile 10 \%$ fat $-20 \%$ fat $-30 \%$ fat

FIGURE 1. Evolution of physicochemical parameters during the ripening of dry-ripened "salchichón" from the Celta pig breed with different fat contents (mean and standard deviation of four replicates). 
$(P<0.05)$ affected by the fat content at the end of the ripening, with values of $5.74 \pm 0.02,5.67 \pm 0.12$ and $5.53 \pm 0.06$ in the batches manufactured with $10 \%, 20 \%$ and $30 \%$ fat, respectively. Initial pH values decreased significantly during the first 21 days of ripening and then they experienced a subsequent increase until the end of the process. The lowest $\mathrm{pH}$ values were observed after 21 days of ripening and they were $5.58 \pm 0.01$ in the $10 \%$ fat batch, $5.41 \pm 0.04$ in the $20 \%$ fat batch and $5.40 \pm 0.01$ in the $30 \%$ fat batch. The initial decrease in $\mathrm{pH}$ values may be due to the production of lactic acid by lactic acid bacteria fermentation of carbohydrates (Lücke, 1994), while the following increase may be the result of the liberation of peptides, amino acids and ammonia from proteolytic reactions (Spaziani et al., 2009). Concerning the effect of fat content on $\mathrm{pH}$ evolution, the results obtained in this work are in agreement with those reported by Gómez and Lorenzo (2013), who stated that "chorizo" from the Celta pig breed manufactured with $10 \%$ fat content showed a less significant $\mathrm{pH}$ decline than those with higher fat contents. Nevertheless, the trend reported in similar studies (Soyer et al., 2005; Olivares et al., 2010; Lorenzo and Franco, 2012) showed a greater decrease in $\mathrm{pH}$ values in sausages manufactured with the lowest fat content, while other authors (Liaros et al., 2009; Salazar et al., 2009) observed that the effect of fat level on $\mathrm{pH}$ evolution throughout the ripening was not significant.

Concerning the study of lipid oxidation, it was evaluated by measuring TBARS throughout ripening. As expected, this parameter increased significantly $(P<0.01)$ as this process progressed, particularly from day 21 until the end of ripening. An increase in TBAR values throughout the ripening process was also observed in previous works when studying dry-ripened sausages (Lorenzo and Franco, 2012; Lorenzo et al., 2012c; Gómez and Lorenzo, 2013). The influence of fat content on TBAR values was not detected until day 35 of dry-ripening, when the $20 \%$ and $30 \%$ fat batches showed significantly $(P<0.05)$ lower values than the $10 \%$ fat batch. At the end of the ripening, the TBAR values found in $10 \%, 20 \%$ and $30 \%$ fat "salchichón" were $0.847 \pm 0.184,0.745 \pm 0.018$ and $0.577 \pm 0.045 \mathrm{mg} \mathrm{MA} / \mathrm{kg}$ sausage, respectively. A similar trend for TBARS was observed by Muguerza et al. (2003), who reported higher TBAR values in low fat sausages which they attributed to the higher oxidation status of intramuscular fat whose percentages increased with the reduction in fat. However, some controversy exists regarding the lipid oxidation of fat-reduced fermented meat products, since several authors (Olivares et al., 2011; Gómez and Lorenzo, 2013) reached the opposite conclusion when studying the TBAR index of similar products.
The values corresponding to the color and textural parameters throughout the ripening of "salchichón" are shown in Table 1 . In general, the color parameters $\left(\mathrm{L}^{*}, \mathrm{a}^{*}\right.$ and $\left.\mathrm{b}^{*}\right)$ of the sausages were affected by both fat level and ripening time, with the effect of the latter being the most evident in all batches. Lightness $\left(\mathrm{L}^{*}\right)$ values decreased significantly during the ripening, yielding darker sausages as the process progresses, probably due to moisture loss (Olivares et al., 2010; Gómez and Lorenzo, 2013). A significant positive correlation between $\mathrm{L}^{*}$ values and moisture $(\mathrm{r}=0.485, P<0.01)$ and water activity ( $\mathrm{r}=0.625, P<0.01)$ was found. Lightness descent was less pronounced in $30 \%$ fat sausages, which exhibited the highest lightness value at day 0 (53.28) and also reached the highest value (45.92) at the end of the ripening when comparing the different "salchichón" batches, as was expected, since lean meat is usually darker than back fat. A similar behavior was previously reported by other authors in analogous studies (Olivares et al., 2010). Regarding redness $\left(a^{*}\right)$ and yellowness $\left(b^{*}\right)$, these parameters experienced significant $(P<0.001)$ changes throughout the ripening with comparable values to those reported by other authors in similar studies (Casquete et al., 2011), but they were not significantly affected by fat level at the end of the process. The possible reason for the decrease in redness values might be partial or total denaturation of nitrosomyoglobin because of the production of lactic acid (Pérez-Álvarez et al., 1999), while yellowness is a color parameter that could be related to lipid oxidation. A significant negative correlation between $b^{*}$ values and TBAR index $(r=-0.689, P<0.01)$ was found.

With regard to the textural properties of "salchichón", evaluated using a TPA test, different trends were observed in the parameters studied. Hardness and chewiness experienced a significant $(P<0.001)$ increase during the ripening period, cohesiveness was significantly $(P<0.001)$ affected by ripening time only in the $10 \%$ and $20 \%$ fat batches and springiness remained stable throughout the process. An increase in hardness and chewiness was also found by several authors in low-fat dry-fermented sausages (Salazar et al., 2009; Olivares et al., 2010). The effect of the different fat contents on textural properties was also dissimilar. Significant $(P<0.01)$ differences were found when comparing the hardness and chewiness of $10 \%, 20 \%$ and $30 \%$ fat sausages at the end of the ripening, showing these latter the lowest values for both parameters, representing around half of those exhibited by $10 \%$ and $20 \%$ fat batches. These results are in agreement with those found by Lorenzo and Franco (2012) and Gómez and Lorenzo (2013), who reported higher hardness in low-fat sausages compared to high-fat ones, probably due to a more pronounced moisture loss in sausages with higher proportions of lean meat. On the other hand, springiness and cohesiveness were 
TABLE 1. Evolution of color and textural properties during the ripening of dry-ripened "salchichón" from the Celta pig breed with different fat contents (mean and standard deviation of four replicates)

\begin{tabular}{|c|c|c|c|c|c|c|c|c|c|c|c|c|}
\hline & \multirow[b]{3}{*}{ Fat content } & \multicolumn{10}{|c|}{ Days of ripening } & \multirow[b]{3}{*}{ Significance } \\
\hline & & \multicolumn{2}{|l|}{$\mathbf{0}$} & \multicolumn{2}{|l|}{7} & \multicolumn{2}{|c|}{21} & \multicolumn{2}{|l|}{35} & \multicolumn{2}{|c|}{49} & \\
\hline & & Mean & SD & Mean & SD & Mean & SD & Mean & SD & Mean & SD & \\
\hline \multicolumn{13}{|l|}{ Color parameters } \\
\hline \multirow[t]{3}{*}{ Lightness $\left(\mathrm{L}^{*}\right)$} & $10 \%$ & $46.77^{\mathrm{d}}$ & 3.94 & $42.75^{c}{ }_{x}$ & 1.81 & $35.56^{b}{ }_{x}$ & 2.20 & $28.81^{a}{ }_{x}$ & 1.27 & $31.17_{x}^{a}$ & 1.46 & $* * *$ \\
\hline & $20 \%$ & $49.18^{\mathrm{c}}$ & 2.37 & $45.24^{\mathrm{bc}}{ }_{\mathrm{xy}}$ & 2.43 & $43.74_{y}^{\mathrm{bc}}$ & 4.56 & $38.64_{y}^{a b}$ & 6.59 & $33.17_{x}^{a}$ & 3.98 & $* *$ \\
\hline & $30 \%$ & $53.28^{\mathrm{c}}$ & 5.43 & $49.81_{y}^{\mathrm{bc}}$ & 2.74 & $51.69^{c}$ & 1.54 & $44.81_{y}^{\mathrm{a}}$ & 1.75 & $45.92^{\mathrm{ab}} \mathrm{y}$ & 2.99 & $* *$ \\
\hline Sign. & & n.s. & & $* *$ & & n.s. & & $* *$ & & $* * *$ & & \\
\hline \multirow[t]{3}{*}{ Redness (a*) } & $10 \%$ & $19.39^{\mathrm{c}}$ & 2.72 & $12.45^{\mathrm{a}}$ & 0.93 & $22.61_{x}^{d}$ & 0.88 & $16.43^{\mathrm{b}}$ & 0.93 & $17.47^{\mathrm{bc}}$ & 1.02 & $* * *$ \\
\hline & $20 \%$ & $18.83^{\text {cd }}$ & 1.30 & $12.52^{\mathrm{a}}$ & 1.26 & $20.64_{x y}^{d}$ & 1.99 & $14.72^{\mathrm{ab}}$ & 2.22 & $17.40^{\mathrm{bc}}$ & 1.80 & $* * *$ \\
\hline & $30 \%$ & $17.34^{\mathrm{bc}}$ & 1.98 & $12.25^{\mathrm{a}}$ & 0.86 & $19.54_{y}^{\mathrm{c}}$ & 1.43 & $16.82^{\mathrm{b}}$ & 0.29 & $15.58^{\mathrm{b}}$ & 2.38 & $* * *$ \\
\hline Sign. & & n.s. & & n.s. & & $*$ & & n.s. & & n.s. & & \\
\hline \multirow[t]{3}{*}{ Yellowness (b*) } & $10 \%$ & $15.52^{\mathrm{c}}$ & 1.37 & $12.81^{\mathrm{b}}$ & 1.28 & $14.73^{\mathrm{c}}$ & 0.82 & $10.78^{a}$ & 0.73 & $10.88^{\mathrm{a}}$ & 0.44 & $* * *$ \\
\hline & $20 \%$ & $16.05^{\mathrm{c}}$ & 0.78 & $12.83^{\mathrm{b}}{ }_{\mathrm{x}}$ & 0.67 & $14.61^{\mathrm{bc}}$ & 1.80 & $9.81_{x}^{a}$ & 1.08 & $10.58^{\mathrm{a}}$ & 1.19 & $* * *$ \\
\hline & $30 \%$ & $15.22^{\text {cd }}$ & 0.79 & $14.38^{\mathrm{bc}}$ & 0.21 & $16.50^{\mathrm{d}}$ & 0.58 & $12.47_{y}^{\mathrm{ab}}$ & 0.36 & $11.23^{\mathrm{a}}$ & 2.50 & $* * *$ \\
\hline Sign. & & n.s. & & * & & n.s. & & $* *$ & & n.s. & & \\
\hline \multicolumn{13}{|l|}{ TPA test } \\
\hline \multirow[t]{3}{*}{ Hardness (kg) } & $10 \%$ & $1.56^{\mathrm{a}}{ }_{\mathrm{x}}$ & 0.04 & $11.35^{\mathrm{b}}{ }_{\mathrm{x}}$ & 3.46 & $28.17^{c}{ }_{x}$ & 3.03 & $41.19^{d}{ }_{x}$ & 2.57 & $42.62^{d}{ }_{x}$ & 2.32 & $* * *$ \\
\hline & $20 \%$ & $1.02^{\mathrm{a}}{ }_{\mathrm{y}}$ & 0.16 & $9.45^{\mathrm{a}}$ & 2.18 & $21.78^{\mathrm{b}}$ & 1.18 & $25.83^{\mathrm{b}}$ & 6.55 & $36.39^{c}{ }_{x}$ & 11.28 & $* * *$ \\
\hline & $30 \%$ & $0.84_{y}^{a}$ & 0.04 & $4.65^{\mathrm{b}} \mathrm{y}$ & 1.39 & $12.36_{\mathrm{z}}^{\mathrm{c}}$ & 1.48 & $12.78_{\mathrm{z}}^{\mathrm{c}}$ & 1.40 & $20.39_{y}^{d}$ & 3.39 & $* * *$ \\
\hline Sign. & & $* * *$ & & $*$ & & $* * *$ & & $* * *$ & & $* *$ & & \\
\hline \multirow[t]{3}{*}{ Springiness (mm) } & $10 \%$ & $0.45^{\mathrm{a}}$ & 0.04 & $0.46^{\mathrm{ab}}$ & 0.03 & $0.47^{\mathrm{ab}}{ }_{\mathrm{x}}$ & 0.00 & $0.51^{\mathrm{b}}$ & 0.02 & $0.49^{\mathrm{ab}}$ & 0.02 & n.s. \\
\hline & $20 \%$ & 0.57 & 0.12 & 0.48 & 0.02 & $0.54_{y}$ & 0.02 & 0.49 & 0.04 & 0.50 & 0.03 & n.s. \\
\hline & $30 \%$ & $0.68^{\mathrm{b}}$ & 0.20 & $0.53^{\mathrm{ab}}$ & 0.07 & $0.55^{\mathrm{ab}}$ & 0.06 & $0.52^{\mathrm{a}}$ & 0.06 & $0.52^{\mathrm{a}}$ & 0.02 & n.s. \\
\hline Sign. & & n.s. & & n.s. & & $*$ & & n.s. & & n.s. & & \\
\hline \multirow[t]{3}{*}{ Cohesiveness } & $10 \%$ & $0.33^{\mathrm{a}}$ & 0.03 & $0.30^{\mathrm{a}}$ & 0.03 & $0.42^{\mathrm{bc}}$ & 0.02 & $0.44_{x}^{c}$ & 0.01 & $0.39^{\mathrm{b}}$ & 0.01 & $* * *$ \\
\hline & $20 \%$ & $0.36^{\mathrm{b}}$ & 0.01 & $0.29^{\mathrm{a}}$ & 0.05 & $0.42^{\mathrm{c}}$ & 0.03 & $0.41_{\mathrm{x}}^{\mathrm{bc}}$ & 0.02 & $0.39^{\mathrm{bc}}$ & 0.01 & $* * *$ \\
\hline & $30 \%$ & $0.39^{\mathrm{b}}$ & 0.04 & $0.28^{\mathrm{a}}$ & 0.06 & $0.37^{\mathrm{b}}$ & 0.03 & $0.35^{\mathrm{ab}}$ & 0.05 & $0.33^{\mathrm{ab}}$ & 0.07 & n.s. \\
\hline Sign. & & n.s. & & n.s. & & n.s. & & $*$ & & n.s. & & \\
\hline \multirow[t]{3}{*}{ Chewiness $\left(\mathrm{kg}^{*} \mathrm{~mm}\right)$} & $10 \%$ & $0.24^{\mathrm{a}}$ & 0.05 & $1.62^{b}$ & 0.68 & $5.53^{c}{ }_{x}$ & 0.82 & $9.12_{\mathrm{x}}^{\mathrm{e}}$ & 0.30 & $8.01_{x}^{d}$ & 0.36 & $* * *$ \\
\hline & $20 \%$ & $0.20^{\mathrm{a}}$ & 0.02 & $1.29_{\mathrm{xy}}^{\mathrm{a}}$ & 0.36 & $4.97^{b} x$ & 0.57 & $5.21_{y}^{\mathrm{bc}}$ & 1.54 & $7.09^{c}{ }_{x}$ & 2.15 & $* * *$ \\
\hline & $30 \%$ & $0.22^{\mathrm{a}}$ & 0.07 & $0.66^{\mathrm{a}}$ & 0.15 & $2.49_{y}^{\mathrm{b}}$ & 0.41 & $2.30^{\mathrm{b}} \mathrm{z}$ & 0.33 & $3.48_{\mathrm{y}}^{\mathrm{c}}$ & 0.95 & $* * *$ \\
\hline Sign. & & n.s. & & $*$ & & $* * *$ & & $* * *$ & & $* *$ & & \\
\hline
\end{tabular}

${ }^{\mathrm{a}-\mathrm{e}}:$ : Mean values in the same row (corresponding to the same fat content) not followed by a common superscript letter differ significantly $(P<0.05$, Duncan test).

${ }^{x-z}$ : Mean values in the same column (corresponding to the same days of ripening) not followed by a common subscript letter differ significantly $(P<0.05$, Duncan test).

SD: Standard deviation.

Significance: n.s.: not significant; $*(P<0.05)$; ** $(P<0.01)$; *** $(P<0.001)$.

in general not significantly affected by fat content. Generally, the major changes in fermented sausage structure take place during fermentation when the $\mathrm{pH}$ declines and myofibrillar proteins aggregate to form a gel. After fermentation, drying is a major factor affecting binding and rheological properties (González-Fernández et al., 2006). Therefore, TPA parameters are correlated $(P<0.01)$ with moisture (hardness: $\mathrm{r}=-0.717$; chewiness: $\mathrm{r}=-0.680$ ) and $\mathrm{a}_{\mathrm{w}}$ (hardness: $r=-0.800$; chewiness: $r=-0.751$ ).

\subsection{Free fatty acid evolution}

Free fatty acid evolution throughout the ripening of "salchichón" is shown in Table 2. Free fatty acid (FFA) content (expressed as mg/100g dry matter) showed similar values $(P<0.05)$, around $130 \mathrm{mg} \cdot 100 \mathrm{~g}^{-1}$ of dry matter, at the beginning of the ripening process, which represented between a $0.2-0.3 \%$ of the total fat content. In the three batches studied, the totalFFA release was significantly affected 
Physicochemical and sensory properties of Celta dry-ripened "salchichón" as affected by fat content • 7

TABLE 2. Evolution of free fatty acid concentrations (mg/100g dry matter) during the ripening of dry-ripened "salchichón" from the Celta pig breed with different fat contents (mean and standard deviation of four replicates)

\begin{tabular}{|c|c|c|c|c|c|c|c|c|c|c|c|c|}
\hline \multirow[b]{3}{*}{ Fatty acid } & \multirow[b]{3}{*}{ Fat content } & \multicolumn{10}{|c|}{ Days of ripening } & \multirow[b]{3}{*}{ Significance } \\
\hline & & \multicolumn{2}{|l|}{$\mathbf{0}$} & \multicolumn{2}{|c|}{7} & \multicolumn{2}{|c|}{21} & \multicolumn{2}{|c|}{35} & \multicolumn{2}{|c|}{49} & \\
\hline & & Mean & SD & Mean & SD & Mean & SD & Mean & SD & Mean & SD & \\
\hline \multirow[t]{3}{*}{ C16:0 } & $10 \%$ & $20.72^{\mathrm{ab}}$ & 13.47 & $12.84_{x}^{\mathrm{a}}$ & 9.03 & $49.58^{\mathrm{c}}$ & 12.47 & $36.75^{\mathrm{bc}}$ & 18.33 & $108.95^{\mathrm{d}}$ & 10.42 & $* * *$ \\
\hline & $20 \%$ & $23.91^{\mathrm{a}}$ & 7.26 & $27.84_{x y}^{a}$ & 6.97 & $33.76^{\mathrm{a}}$ & 16.76 & $53.21^{\mathrm{a}}$ & 13.10 & $164.17_{\mathrm{y}}^{\mathrm{b}}$ & 37.02 & $* * *$ \\
\hline & $30 \%$ & $34.53^{\mathrm{a}}$ & 20.96 & $40.91_{y}^{a}$ & 15.49 & $48.94^{\mathrm{a}}$ & 16.24 & $26.62^{\mathrm{a}}$ & 19.21 & $151.18_{\mathrm{y}}^{\mathrm{b}}$ & 21.19 & $* * *$ \\
\hline Sign. & & n.s. & & * & & n.s. & & n.s. & & $*$ & & \\
\hline \multirow[t]{3}{*}{ C18:0 } & $10 \%$ & $11.89^{\mathrm{ab}}$ & 6.88 & $6.69^{\mathrm{a}}{ }_{\mathrm{x}}$ & 3.88 & $22.42^{\mathrm{c}}$ & 4.05 & $18.01^{\mathrm{bc}}$ & 7.86 & $50.78_{x}^{d}$ & 4.89 & $* * *$ \\
\hline & $20 \%$ & $14.53^{\mathrm{a}}$ & 2.91 & $15.22^{\mathrm{a}} \mathrm{ay}$ & 2.72 & $16.87^{\mathrm{a}}$ & 8.05 & $26.28^{\mathrm{a}}$ & 6.50 & $76.33^{\mathrm{b}} \mathrm{y}$ & 18.34 & $* * *$ \\
\hline & $30 \%$ & $22.64^{\mathrm{a}}$ & 13.48 & $22.88_{y}^{\mathrm{a}}$ & 8.30 & $26.70^{\mathrm{a}}$ & 8.02 & $14.47^{\mathrm{a}}$ & 8.02 & $66.97^{\mathrm{b}} \mathrm{by}$ & 12.32 & $* * *$ \\
\hline Sign. & & n.s. & & $* *$ & & n.s. & & n.s. & & n.s. & & \\
\hline \multirow[t]{3}{*}{ SFA } & $10 \%$ & $32.61^{\mathrm{ab}}$ & 20.34 & $19.54^{\mathrm{a}}$ & 12.89 & $72.00^{\mathrm{c}}$ & 16.21 & $54.75^{\mathrm{bc}}$ & 26.07 & $159.73^{d}$ & 14.24 & $* * *$ \\
\hline & $20 \%$ & $38.44^{\mathrm{a}}$ & 9.82 & $43.06_{x y}^{\mathrm{a}}$ & 9.41 & $50.63^{\mathrm{a}}$ & 24.75 & $79.48^{\mathrm{a}}$ & 19.44 & $240.50^{\mathrm{b}}$ & 54.42 & $* * *$ \\
\hline & $30 \%$ & $57.16^{\mathrm{a}}$ & 34.27 & $63.79_{y}^{a}$ & 23.75 & $75.64^{\mathrm{a}}$ & 24.19 & $41.09^{\mathrm{a}}$ & 27.22 & $218.15^{\mathrm{a}}{ }_{\mathrm{ay}}$ & 32.51 & $* * *$ \\
\hline Sign. & & n.s. & & * & & n.s. & & n.s. & & $*$ & & \\
\hline \multirow[t]{3}{*}{ C16:1 } & $10 \%$ & ND & & ND & & 2.54 & 1.54 & 2.79 & 0.32 & ND & & $* * *$ \\
\hline & $20 \%$ & ND & & ND & & 1.20 & 0.57 & 2.47 & 2.65 & ND & & $*$ \\
\hline & $30 \%$ & ND & & ND & & 1.54 & 0.33 & ND & & ND & & $* * *$ \\
\hline Sign. & & - & & - & & n.s. & & n.s. & & - & & \\
\hline \multirow[t]{3}{*}{$\mathrm{C} 18: \ln 9 \mathrm{c}$} & $10 \%$ & $55.27^{\mathrm{a}}{ }_{\mathrm{x}}$ & 23.34 & $25.27^{\mathrm{a}}{ }_{\mathrm{x}}$ & 17.02 & $101.93^{\mathrm{b}}{ }_{\mathrm{xy}}$ & 15.31 & $97.90^{\mathrm{b}}$ & 24.37 & $195.37^{c}{ }_{x}$ & 27.58 & $* * *$ \\
\hline & $20 \%$ & $61.89^{\mathrm{a}}{ }_{\mathrm{x}}$ & 10.10 & $78.26_{y}^{a}$ & 14.08 & $94.92^{\mathrm{ab}}{ }_{\mathrm{x}}$ & 24.79 & $133.34^{\mathrm{b}}$ & 36.17 & $301.72_{\mathrm{y}}^{\mathrm{c}}$ & 40.22 & $* * *$ \\
\hline & $30 \%$ & $100.43^{\mathrm{a}}{ }_{\mathrm{y}}$ & 32.75 & $120.81^{\mathrm{a}}{ }_{\mathrm{y}}$ & 40.81 & $135.16_{\mathrm{y}}^{\mathrm{a}}$ & 29.71 & $110.24^{\mathrm{a}}$ & 36.17 & $303.27^{\mathrm{b}} \mathrm{y}$ & 34.12 & $* * *$ \\
\hline Sign. & & n.s. & & $* *$ & & n.s. & & n.s. & & $* *$ & & \\
\hline \multirow[t]{3}{*}{ MUFA } & $10 \%$ & $55.27^{\mathrm{a}}{ }_{\mathrm{x}}$ & 23.34 & $25.27^{a}{ }_{x}$ & 17.02 & $104.47^{\mathrm{b}}$ & 16.78 & $100.70^{\mathrm{b}}$ & 24.28 & $195.37^{c}{ }_{x}$ & 27.58 & $* * *$ \\
\hline & $20 \%$ & $61.89^{a}{ }_{x}^{a}$ & 10.10 & $78.26^{\mathrm{a}}{ }_{\mathrm{y}}$ & 14.08 & $96.12^{\mathrm{ab}}$ & 25.08 & $135.81^{\mathrm{b}}$ & 38.67 & $301.72_{\mathrm{y}}^{\mathrm{c}}$ & 40.22 & $* * *$ \\
\hline & $30 \%$ & $100.43_{y}^{\mathrm{a}}$ & 32.75 & $120.81_{y}^{a}$ & 40.81 & $136.70^{\mathrm{a}}$ & 29.76 & $110.24^{\mathrm{a}}$ & 36.17 & $303.27_{y}^{\mathrm{b}}$ & 34.12 & $* * *$ \\
\hline Sign. & & n.s. & & $* *$ & & n.s. & & n.s. & & $* *$ & & \\
\hline \multirow[t]{3}{*}{$\mathrm{C} 18: 2 \mathrm{n} 6 \mathrm{c}$} & $10 \%$ & $14.57^{\mathrm{a}}$ & 4.44 & $16.71^{\mathrm{a}}{ }_{\mathrm{x}}$ & 4.18 & $40.61^{b}$ & 5.89 & $37.60^{b}{ }_{x}$ & 10.97 & $106.29^{c}{ }_{x}$ & 9.34 & $* * *$ \\
\hline & $20 \%$ & $17.09^{\mathrm{a}}$ & 6.53 & $21.31_{x y}^{a}$ & 5.99 & $35.92^{\mathrm{ab}}$ & 8.93 & $57.06^{\mathrm{b}}$ & 6.56 & $148.49^{\mathrm{c}}$ & 28.47 & $* * *$ \\
\hline & $30 \%$ & $22.37^{\mathrm{a}}$ & 7.93 & $28.55^{\mathrm{ab}}{ }_{\mathrm{y}}$ & 8.51 & $43.32^{\mathrm{b}}$ & 9.01 & $45.67^{\mathrm{b}}{ }_{\mathrm{xy}}$ & 9.70 & $126.63_{x y}^{c}$ & 19.29 & $* * *$ \\
\hline Sign. & & n.s. & & n.s. & & n.s. & & $*$ & & n.s. & & \\
\hline \multirow[t]{3}{*}{ C20:4n6 } & $10 \%$ & ND & & $0.93^{\mathrm{a}}$ & 1.19 & $2.55^{\mathrm{b}}$ & 0.43 & $2.81_{x y}^{b}$ & 0.83 & ND & & $* * *$ \\
\hline & $20 \%$ & ND & & $0.98^{\mathrm{a}}$ & 1.15 & $1.90^{\mathrm{ab}}$ & 2.28 & $3.68_{x}^{b}$ & 1.49 & ND & & $* *$ \\
\hline & $30 \%$ & ND & & ND & & 1.05 & 1.27 & $1.38_{\mathrm{y}}$ & 1.10 & ND & & $*$ \\
\hline Sign. & & - & & n.s. & & n.s. & & n.s. & & - & & \\
\hline \multirow[t]{3}{*}{ PUFA } & $10 \%$ & $14.57^{\mathrm{a}}$ & 4.44 & $17.64^{\mathrm{a}}$ & 4.94 & $43.16^{\mathrm{b}}$ & 6.10 & $40.40^{b}{ }_{x}$ & 11.62 & $106.29^{c}{ }_{x}$ & 9.34 & $* * *$ \\
\hline & $20 \%$ & $17.09^{\mathrm{a}}$ & 6.53 & $22.30^{\mathrm{a}}$ & 6.68 & $37.82^{\mathrm{a}}$ & 11.19 & $60.75^{\mathrm{b}} \mathrm{y}$ & 7.27 & $148.49_{\mathrm{y}}^{\mathrm{c}}$ & 28.47 & $* * *$ \\
\hline & $30 \%$ & $22.37^{\mathrm{a}}$ & 7.93 & $28.55^{\mathrm{ab}}$ & 8.51 & $44.37^{\mathrm{b}}$ & 9.86 & $47.05^{\mathrm{b}}{ }_{\mathrm{xy}}$ & 9.22 & $126.63_{\mathrm{xy}}^{\mathrm{c}}$ & 19.29 & $* * *$ \\
\hline Sign. & & n.s. & & n.s. & & n.s. & & $*$ & & n.s. & & \\
\hline \multirow[t]{3}{*}{ Total } & $10 \%$ & $102.44^{\mathrm{a}}$ & 47.40 & $62.44_{x}^{\mathrm{a}}$ & 6.69 & $219.64^{\mathrm{b}}$ & 36.67 & $195.86^{\mathrm{b}}$ & 60.35 & $461.39^{c}{ }_{x}$ & 46.15 & $* * *$ \\
\hline & $20 \%$ & $117.41^{\mathrm{a}}$ & 22.61 & $143.62^{\mathrm{a}}{ }_{\mathrm{xy}}$ & 29.66 & $184.57^{\mathrm{ab}}$ & 59.86 & $276.04^{b}$ & 62.86 & $690.71_{\mathrm{y}}^{\mathrm{c}}$ & 121.27 & $* * *$ \\
\hline & $30 \%$ & $179.96^{\mathrm{a}}$ & 74.83 & $213.15^{\mathrm{a}} \mathrm{y}$ & 73.01 & $256.71^{\mathrm{a}}$ & 63.07 & $198.38^{\mathrm{a}}$ & 72.40 & $648.05^{\mathrm{b}}{ }_{\mathrm{xy}}$ & 79.36 & $* * *$ \\
\hline Sign. & & n.s. & & $* *$ & & n.s. & & n.s. & & $*$ & & \\
\hline
\end{tabular}

${ }^{\mathrm{a}-\mathrm{d}}$ : Mean values in the same row (corresponding to the same fat content) not followed by a common superscript letter differ significantly $(P<0.05$, Ducan test $)$.

${ }^{x-y}$ : Mean values in the same column (corresponding to the same days of ripening) not followed by a common subscript letter differ significantly $(P<0.05$, Ducant test).

SFA: Saturated fatty acids; MUFA: Monounsaturated fatty acids; PUFA: Polyunsaturated fatty acids; SD: Standard deviation.

ND: not detected; Significance: $n$.s.: not significant; $*(P<0.05) ;{ }^{* *}(P<0.01) ;{ }^{* * *}(P<0.001)$. 
$(P<0.001)$ by ripening time. Due to the lipolysis phenomena (Gandemer, 2002), the total FFA concentration increased throughout the dry-ripening. At the end of the process, the $20 \%$ fat sausages showed significantly $(P<0.05)$ higher FFA contents $(690.71 \mathrm{mg} / 100 \mathrm{~g}$ dry matter) than the $10 \%$ fat sausages (461.39 mg.100 $\mathrm{g}^{-1}$ dry matter), meanwhile the $30 \%$ fat sausages presented intermediate values (648.05 $\mathrm{mg} \cdot 100 \mathrm{~g}^{-\mathrm{f}}$ dry matter). These FFA amounts represented between $1-1.3 \%$ of the total fat content, similar in the three "salchichón" batches. Other authors, in analogous studies (Olivares et al., 2011; Lorenzo and Franco, 2012), also found a minor degree of lipolysis in reduced-fat sausages. At the end of the ripening, the main FFAs by order of amount were as follows: oleic, palmitic, linoleic and stearic acid. Moreover, small quantities of palmitoleic and arachidonic acids were found too. Similar FFA contents were obtained in analogous dry-ripened sausages (Lorenzo and Franco, 2012; Gómez and Lorenzo, 2013). However, Bruna et al. (2000) reported a more intense lipolytic activity in dry-cured sausages.

The FFA percentage at day 0 in all batches showed the relationship MUFA $>$ SFA $>$ PUFA as previously observed by other authors (Olivares et al., 2011; Gómez and Lorenzo, 2013) and this relation was maintained during the ripening process. However, the PUFA content increased during the manufacturing process by approximately 7 times, whereas SFA increased by 5 times and MUFA by only 3.8 times. At the end of the manufacturing process, the fatty acid total relative percentage (Fig. 2) was significantly $(P<0.05)$ affected by fat level, thus the MUFA percentage was higher for $30 \%$ fat sausages than for $10 \%$ fat ones ( $46.8 \%$ vs. $42.34 \%$ ) and on the contrary for the PUFA percentage (19.5\% vs. $23.0 \%$ ), whereas SFA percentages were not affected.

As several authors indicated (Navarro et al., 1997; Gómez and Lorenzo, 2013), throughout the ripening process of fermented sausages, phospholipids, due to their high content in PUFA, are the main source of release of these fatty acids, while MUFA are liberated mainly from triglycerides, which are richer in mono-unsaturated fats (Navarro et al., 2001). In adipose tissue, FFA comes mainly from triglycerides (Coutron-Gambotti and Gandemer, 1999) while in muscle, both triglycerides and phospholipids contribute to fatty acid release (Gandemer, 2002). The higher proportion of PUFA in fat-reduced sausages at the end of the ripening process could be related to the lower content of adipose tissue in the sausage formulation, so that the phospholipid hydrolysis turned out to be more pronounced in these sausages. In high-fat sausages, however, the great adipose tissue content of the sausages makes the triglyceride hydrolysis more prominent. Despite the great increase in PUFA contents (about 7 times, as previously mentioned) in the three types of sausages during ripening, total content in MUFA $(\mathrm{mg} / 100 \mathrm{~g}$ dry matter) was higher than PUFA, so it could be assumed that the main source of FFA was the triglycerides, both from muscle and adipose tissue.

\subsection{Volatile compound profile}

In total, 32 volatile compounds were identified and quantified in "salchichón" from the Celta pig breed formulated with different fat contents using an SPME-GC/MS method after 49 days of

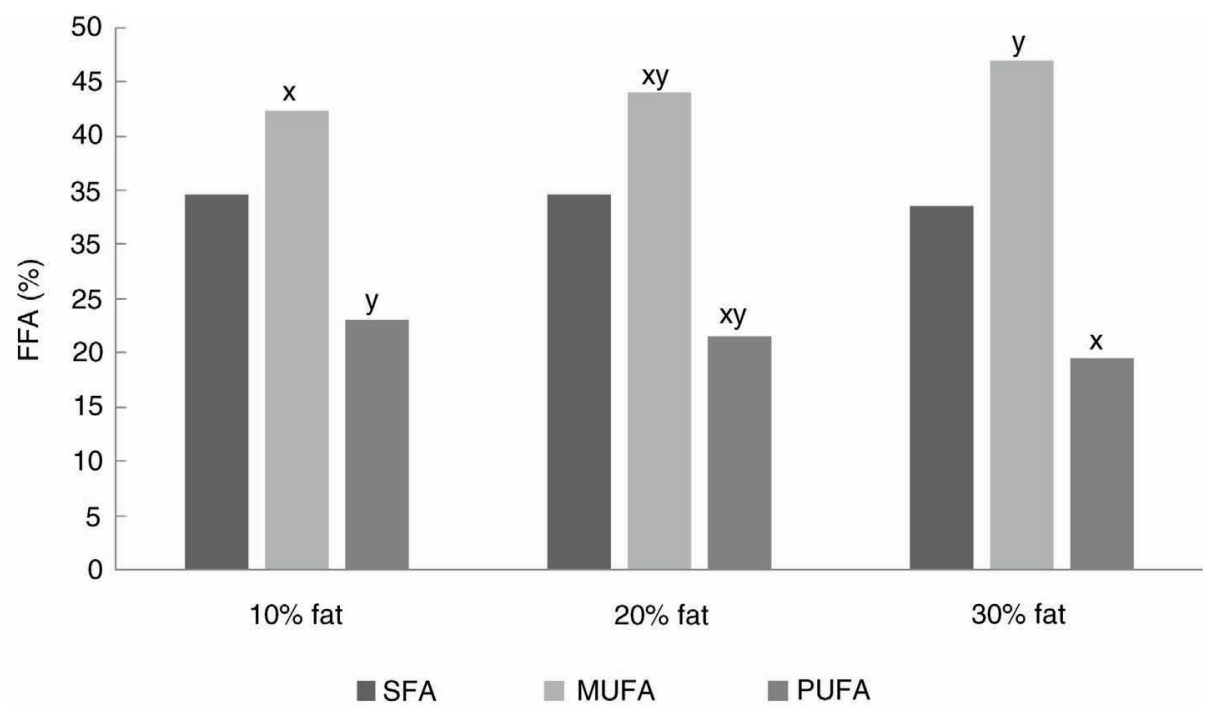

FIGURE 2. Total relative percentage of saturated (SFA), monounsaturated (MUFA) and polyunsaturated (PUFA) fatty acids from the free fatty acid fraction at the end of the ripening process. ${ }^{\mathrm{x}-\mathrm{y}}$ Mean values (corresponding to the same fatty acid group not followed by a common subscript letter differ significantly $(P<0.05$, Duncan test). 
TABLE 3. Volatile compounds (area units $\times 10^{6} \cdot \mathrm{g}^{-1}$ dry matter) of dry-ripened "salchichón" from the Celta pig breed at the end of ripening made with different fat contents (means and standard deviation of eight replicates)

\begin{tabular}{|c|c|c|c|c|c|c|c|c|c|}
\hline \multirow[b]{3}{*}{ Compound } & \multirow[b]{3}{*}{ KI } & \multirow[b]{3}{*}{$\mathbf{R}$} & \multicolumn{6}{|c|}{ Fat content $(\%)$} & \multirow[b]{3}{*}{ Significanc } \\
\hline & & & \multicolumn{2}{|c|}{10} & \multicolumn{2}{|c|}{20} & \multicolumn{2}{|c|}{30} & \\
\hline & & & Mean & SD & Mean & SD & Mean & SD & \\
\hline \multicolumn{10}{|l|}{ Lipid oxidation } \\
\hline Hexanal & 855 & $\mathrm{~m}, \mathrm{~s}, \mathrm{k}$ & 14.04 & 3.54 & 11.96 & 5.80 & 13.14 & 8.91 & n.s. \\
\hline Heptane, 3,3,5-trimethyl- & 888 & $\mathrm{~m}$ & 4.85 & 7.16 & 8.73 & 2.22 & 8.94 & 1.67 & n.s. \\
\hline Octane, 2,2,6-trimethyl- & 937 & $\mathrm{~m}$ & 19.22 & 7.02 & 19.59 & 3.09 & 14.58 & 0.47 & n.s. \\
\hline Nonane, 3,7-dimethyl- & 1100 & $\mathrm{~m}$ & $24.70^{\mathrm{a}}$ & 7.43 & $15.71^{\mathrm{b}}$ & 2.87 & $14.04^{\mathrm{b}}$ & 3.01 & $*$ \\
\hline Octane, 2,6-dimethyl- & 1102 & $\mathrm{~m}$ & 62.11 & 14.81 & 68.65 & 49.00 & 48.84 & 9.50 & n.s. \\
\hline Undecane, 4-methyl- & 1129 & $\mathrm{~m}$ & 9.19 & 2.78 & 4.69 & 0.00 & 7.71 & 2.30 & n.s. \\
\hline 2-Nonanone & 1168 & $\mathrm{~m}$ & 3.02 & 0.51 & 2.71 & 1.36 & 2.52 & 0.21 & n.s. \\
\hline Benzaldehyde, 2,4bis(trimethylsiloxy)- & 1180 & $\mathrm{~m}$ & 7.74 & 1.84 & 5.86 & 1.88 & 5.67 & 0.62 & n.s. \\
\hline \multicolumn{10}{|l|}{ Carbohydrate fermentation } \\
\hline 2-Butanone, 3-hydroxy- & 774 & $\mathrm{~m}, \mathrm{k}$ & $10.85^{\mathrm{a}}$ & 1.32 & $7.15^{\mathrm{b}}$ & 1.41 & $3.47^{\mathrm{c}}$ & 0.97 & $* * *$ \\
\hline \multicolumn{10}{|l|}{ Amino acid catabolism } \\
\hline 1-Butanol, 3-methyl- & 808 & $\mathrm{~m}, \mathrm{k}$ & $4.05^{\mathrm{a}}$ & 1.82 & $1.92^{\mathrm{ab}}$ & 0.47 & $1.49^{\mathrm{b}}$ & 0.29 & $*$ \\
\hline \multicolumn{10}{|l|}{ Spices } \\
\hline$\alpha$-Pinene & 946 & $\mathrm{~m}$ & 121.39 & 30.11 & 103.00 & 43.58 & 106.13 & 23.91 & n.s. \\
\hline$\alpha$-Phellandrene & 981 & $\mathrm{~m}$ & 280.64 & 42.97 & 178.75 & 114.46 & 203.78 & 63.91 & n.s. \\
\hline$\beta$-Pinene & 982 & $\mathrm{~m}$ & 149.51 & 21.53 & 160.44 & 37.43 & 145.80 & 33.09 & n.s. \\
\hline Terpinolene & 1137 & $\mathrm{~m}$ & $35.12^{\mathrm{a}}$ & 6.68 & $24.88^{\mathrm{b}}$ & 11.98 & $26.74^{\mathrm{ab}}$ & 5.92 & n.s. \\
\hline 4-Terpineol & 1246 & $\mathrm{~m}$ & $29.15^{\mathrm{a}}$ & 3.58 & $19.50^{\mathrm{b}}$ & 8.66 & $19.39^{\mathrm{b}}$ & 3.10 & $* *$ \\
\hline$\alpha$-Terpineol & 1263 & $\mathrm{~m}$ & 4.13 & 0.52 & 3.25 & 0.00 & 2.58 & 0.20 & $* *$ \\
\hline Bornyl acetate & 1329 & $\mathrm{~m}$ & $1.16^{\mathrm{a}}$ & 0.15 & $0.84^{\mathrm{b}}$ & 0.21 & $0.74^{\mathrm{b}}$ & 0.13 & $* *$ \\
\hline Safrole & 1332 & $\mathrm{~m}$ & $32.63^{\mathrm{a}}$ & 9.24 & $22.03^{\mathrm{b}}$ & 11.52 & $21.00^{\mathrm{b}}$ & 5.85 & $*$ \\
\hline$\delta$-Elemene & 1349 & $\mathrm{~m}$ & $6.09^{\mathrm{a}}$ & 1.23 & $3.65^{\mathrm{b}}$ & 0.68 & $3.16^{\mathrm{b}}$ & 1.52 & $* *$ \\
\hline$\alpha$-Cubebene & 1357 & $\mathrm{~m}$ & $1.46^{\mathrm{a}}$ & 0.26 & $0.97^{\mathrm{b}}$ & 0.27 & $0.97^{\mathrm{b}}$ & 0.27 & $* *$ \\
\hline Copaene & 1380 & $\mathrm{~m}$ & $6.72^{\mathrm{a}}$ & 1.48 & $4.27^{\mathrm{b}}$ & 1.08 & $4.53^{\mathrm{b}}$ & 1.88 & $* *$ \\
\hline$\beta$-Elemene & 1394 & $\mathrm{~m}$ & $1.80^{\mathrm{a}}$ & 0.37 & $1.30 \mathrm{~b}$ & 0.62 & $0.90^{\mathrm{b}}$ & 0.28 & $* *$ \\
\hline$\beta$-Caryophyllene & 1409 & $\mathrm{~m}$ & 0.89 & 0.61 & 0.45 & 0.05 & 0.37 & 0.02 & n.s. \\
\hline Methyl eugenol & 1416 & $\mathrm{~m}$ & $7.12 \mathrm{a}$ & 1.28 & $4.48 b$ & 2.06 & $4.55 \mathrm{~b}$ & 1.05 & $* *$ \\
\hline Norcaryophyllene, 5,6-dihydro- & 1426 & $\mathrm{~m}$ & 3.33 & 1.78 & 1.18 & 0.18 & 0.72 & 0.16 & $*$ \\
\hline$\alpha$-Caryophyllene & 1447 & $\mathrm{~m}$ & $2.92^{\mathrm{a}}$ & 0.55 & $1.52^{\mathrm{b}}$ & 0.30 & $1.41^{\mathrm{b}}$ & 0.47 & $* * *$ \\
\hline $\begin{array}{l}\text { 1,4,7,-Cycloundecatriene, } \\
\text { 1,5,9,9-tetramethyl-, Z,Z,Z- }\end{array}$ & 1447 & $\mathrm{~m}$ & 2.43 & 0.69 & 2.03 & 0.33 & 1.40 & 0.30 & n.s. \\
\hline Isomethyl eugenol & 1484 & $\mathrm{~m}$ & $0.72 \mathrm{a}$ & 0.12 & $0.42 b$ & 0.06 & $0.46^{\mathrm{b}}$ & 0.23 & $* *$ \\
\hline Myristicin & 1499 & $\mathrm{~m}$ & $3.84^{\mathrm{a}}$ & 0.71 & $2.40^{\mathrm{b}}$ & 0.65 & $2.14^{\mathrm{b}}$ & 0.60 & $* * *$ \\
\hline \multicolumn{10}{|l|}{ Others and unknown } \\
\hline Toluene & 803 & $\mathrm{~m}, \mathrm{k}$ & 1.25 & 0.19 & 1.01 & 0.23 & 2.00 & 2.16 & n.s. \\
\hline Caprolactam & 1363 & $\mathrm{~m}$ & 0.39 & 0.15 & 0.56 & 0.64 & 0.13 & 0.02 & n.s. \\
\hline Diethyl phthalate & 1536 & $\mathrm{~m}$ & 0.50 & 0.23 & 0.32 & 0.25 & 0.28 & 0.07 & n.s. \\
\hline
\end{tabular}

${ }^{\mathrm{a}-\mathrm{d}}$ : Mean values in the same row (corresponding to the same volatile compound) not followed by a common superscript letter differ significantly $(P<0.05$, Duncan test).

KI: Kovats index; SD: Standard deviation; R: Reliability of identification: k: kovats index in agreement with literature (Lorenzo, 2014; Lorenzo et al., 2014; Lorenzo et al., 2013; Lorenzo et al., 2012b; Olivares et al., 2011; Purriños et al., 2011; Purriños et al., 2012; Purriños et al., 2013); m: mass spectrum agreed with mass database (NIST05); s: mass spectrum and retention time identical to an authentic standard.

Significance: n.s.: not significant; * $(P<0.05)$; ** $(P<0.01)$; *** $(P<0.001)$. 
ripening. The SPME technique is not normally used for absolute quantifications, but when exactly the same extraction methodology is employed, this technique allows for comparing relative amounts among samples (Roberts et al., 2003). Table 3 shows the mean quantities of the identified compounds grouped according to their most probable origins as from lipid oxidation, carbohydrate fermentation, amino acid catabolism and spices. The remaining volatile compounds were grouped as "others or unknown". It should be taken into account that some of the compounds listed could have had more than one source or be the result of secondary reactions between substances derived from different catabolic routes (Berdagué et al., 1993).

In general, all the batches showed a similar profile at the end of the ripening, exhibiting concentrations of volatile compounds derived from spices at least 4 times greater than those derived from any other origin considered. Most compounds identified have been previously reported in Spanish sausages (Lorenzo et al., 2012c, Lorenzo et al., 2013).

Among the 8 lipid-oxidation derived volatile compounds detected, octane, 2,6-dimethyl was the most abundant. Only nonane, 3,7-dimethyl showed significant $(P<0.05)$ differences when comparing the "salchichón" batches manufactured with different fat levels, showing higher contents in the $10 \%$ fat sausages than in the $20 \%$ or $30 \%$ fat batches, possibly due to the higher proportion of intramuscular fat containing unsaturated fatty acids which are more susceptible to oxidation. This compound, as well as all the aliphatic hydrocarbons, has a high odor threshold value so they do not contribute significantly to the aroma of meat products. However, other lipid-oxidation derived volatile compounds, such as aromatic hydrocarbons or aldehydes, have low odor threshold values and play an important role in the flavor of dry-cured meat products (Muriel et al., 2004; Ramírez and Cava, 2007). In particular, benzaldehyde has been associated with a certain almond flavor and it is considered to be one of the substances that give specific flavor notes in pork (Ansorena et al., 2001).

Only one carbohydrate-fermentation derived volatile compound, 2-butanone,3-hydroxy, was extracted from the sausages, exhibiting significant $(P<0.001)$ differences among batches, with contents that followed the relationship $10 \%>20 \%>30 \%$ fat batches. According to Gandemer (2002), 3-hydroxy-2butanone could be originated from carbohydrate fermentation or, according to Buscailhon et al. (1993), from glycogen degradation, which could explain these results, since the $10 \%$ fat batches have a higher proportion of muscle tissue, one of the main sources of glycogen. With respect to volatiles coming from amino acid catabolism, only 1-butanol, 3-methyl was detected. Its content in the sausages was significantly $(P<0.05)$ affected by fat level, being higher in the $10 \%$ fat batches, which could be due to the higher content of protein in these sausages than in the $20 \%$ and $30 \%$ fat ones. This compound, together with other branched volatiles, such as 3-methylbutanal and 2-methylpropanoic acid, have been associated with the characteristic ripened aroma of cured meat products (Ruiz et al., 1999).

Within the group of volatiles derived from added spices, a total of 19 different compounds were extracted from "salchichón" at the end of ripening. The content of most of these compounds was affected by the fat level of the sausages, and was higher in all cases in the $10 \%$ fat batches. Accordingly, it was reported that the release of spice-derived volatile compounds such as terpenes was higher in low fat frankfurter and salami (Chevance et al., 2000). However, dry fermented sausages are meat products subjected to ripening where numerous metabolic and chemical processes occur. Therefore, in dry fermented sausages with different fat contents, fat by itself affects flavor not only due to its role as a flavor precursor but also as a solvent of other volatile compounds (Olivares et al., 2011).

\subsection{Sensory evaluation of final products}

The results of the descriptive sensory analysis of the three batches of 'salchichón' with different fat contents are shown in Fig. 3. Among the 9 descriptors considered, only flavor intensity appeared not to be significantly affected by fat content, showing scores of around 6. Regarding appearance parameters, the scores for fat level were, as expected, significantly $(P<0.01)$ higher for the $30 \%$ fat "salchichón", while fat/lean cohesiveness showed significantly $(P<0.01)$ greater values for $10 \%$ fat sausages. Black pepper odor, saltiness, hardness and dryness were also affected by fat content, showing higher scores when studying the $10 \%$ fat sausages, while the effect of fat level on "salchichón" juiciness exhibited an inverse trend, following the relationship 30\%>20\%>10\% fat batches. This latter attribute is related to the lubrication degree of food during chewing and swallowing and, due to the contribution of fat on saliva secretion, high-fat foods increase juiciness by saliva coating tongue, teeth and other parts of the mouth. Similar results were obtained by Soyer et al. (2005) and Gómez and Lorenzo (2013) in dry-ripened sausages. In general, it has been reported that low and medium fat sausages exhibit greater sensory characteristics when comparing dry-cured sausages with different fat levels (Lorenzo et al., 2012c).

\section{CONCLUSIONS}

The results obtained in this work conducted on "salchichón" from the Celta pig breed formulated with different fat contents indicated that, in 


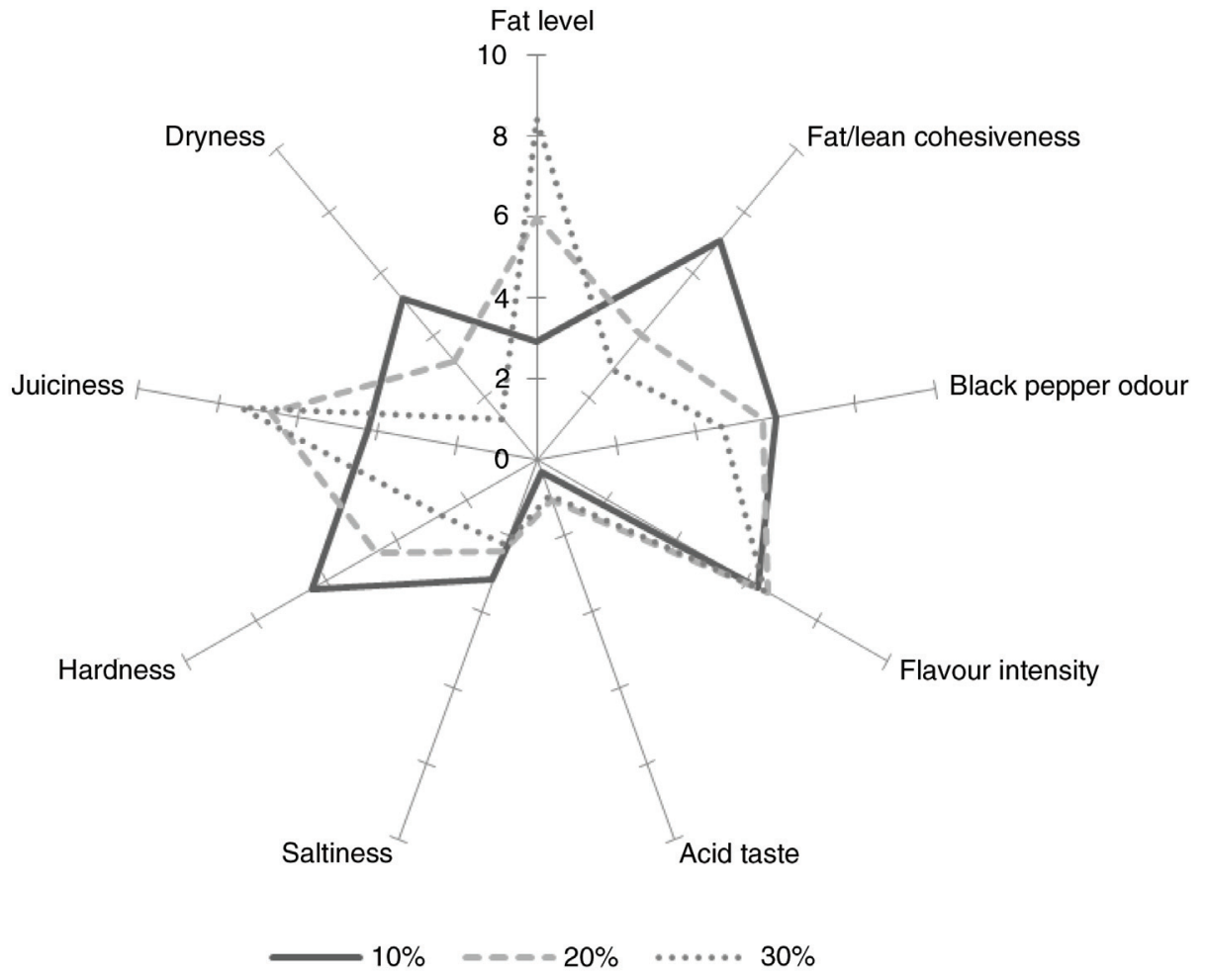

FIGURE 3. Sensory properties of dry-ripened "salchichón" from the Celta pig breed with different fat contents (mean of the scores given by 10 panelists).

general, most of the studied physicochemical, color and textural parameters were significantly affected by fat level. Lipolytic reactions were also enhanced when increasing fat content leading to a higher FFA release. However, the sausages exhibiting a higher content of volatile compounds were those manufactured with the lower fat level $(10 \%$ fat), even though sensory evaluation results, which reflected higher scores for black pepper odor in $10 \%$ fat sausages, did not show significant differences when assessing flavor intensity. Significant differences were obtained for other important sensorial attributes such as dryness and hardness, whose scores increased as fat level was lower, reflecting a preference for the texture of sausages with a relatively high fat content. This latter finding leads us to conclude that, although fat reduction would improve the nutritional quality of dryripened meat products, it can be successful only to a certain extent, and therefore a formulation including $20 \%$ fat would be the most suitable for the elaboration of "salchichón" from the Celta pig breed.

\section{ACKNOWLEDGMENTS}

The authors are grateful to the Xunta de Galicia (The Regional Government) (Project FEADER 2010/15) for financial support.

\section{REFERENCES}

Ansorena D, Gimeno O, Astiasaran I, Bello J. 2001. Analysis of volatile compounds by GC-MS of a dry fermented sausage: chorizo de Pamplona. Food Res. Int. 34, 67-75. http:// dx.doi.org/10.1016/S0963-9969(00)00133-2.

Berdagué JL, Monteil P, Montel MC, Talon R. 1993. Effects of starter cultures on the formation of flavour compounds in dry sausage. Meat. Sci. 35, 275-287. http://dx.doi.org/ 10.1016/0309-1740(93)90033-E.

Bruna JM, Fernández M, Hierro EM, Ordóñez JA, Hoz L. 2000. Improvement of the sensory properties of dry fermented sausages by the superficial inoculation and/or the addition of intracellular extracts of Mucor racemosus. J. Food Sci. 65, 731-738. http://dx.doi.org/10.1111/j.1365-2621.2000. tb16081.x.

Buscailhon S, Berdagué JL, Monin G. 1993. Time-related changes in volatile compounds of lean tissue during processing of French dry-cured ham. J. Sci. Food Agric. 63, 69-75. http://dx.doi.org/10.1002/jsfa.2740630112.

Carreau JP, Dubacq JP. 1978. Adaptation of a macro scale method to the micro scale for fatty acid methyl transesterification of biological lipid extracts. J. Chromatogr. 151, 384-390. http://dx.doi.org/10.1016/S0021-9673(00)88356-9.

Carril JA, Rivero CJ, Fernández M, Lorenzo JM. 2012. La raza, in CETECA (Ed.) Manual del Cerdo Celta, Spain.

Casquete R, Benito MJ, Martín A, Ruiz-Moyano S, Córdoba JJ, Córdoba MG. 2011. Role of an autochthonous starter culture and the protease EPg222 on the sensory and safety properties of a traditional Iberian dry-fermented sausage "salchichón". Food Microbiol. 28, 1432-1440. http:// dx.doi.org/10.1016/j.fm.2011.07.004.

Chevance FF, Farmer LJ, Desmond EM, Novelli E, Troy DJ, Chizzolini R. 2000. Effect of some fat replacers on the release of volatile aroma compounds from low-fat meat products. J. Agric. Food Chem. 48, 3476-3484. http://dx.doi. org/10.1021/jf991211u. 
Coutron-Gambotti C, Gandemer G. 1999. Lipolysis and oxidation in subcutaneous adipose tissue during dry-cured ham processing. Food Chem. 64, 95-101. http://dx.doi. org/10.1016/S0308-8146(98)00079-X.

Ferguson LR, Philpott M, Karunasinghe N. 2004. Dietary cancer and prevention using antimutagens. Toxicology 198 147-159. http://dx.doi.org/10.1016/j.tox.2004.01.035.

Folch J, Lees M, Sloan-Stanley GH. 1957. A simple method for the isolation and purification of total lipides from animal tissues. J. Biol. Chem. 226, 497-509.

Franco D, Vázquez JA, Lorenzo JM. 2014. Growth performance, carcass and meat quality of the Celta pig crossbred with Duroc and Landrace genotypes. Meat Sci. 96, 195-202. http://dx.doi.org/10.1016/j.meatsci.2013.06.024.

Gandemer G. 2002. Lipids in muscles and adipose tissues, changes during processing and sensory properties of meat products. Meat Sci. 62, 309-321. http://dx.doi.org/10.1016/ S0309-1740(02)00128-6.

García-Regueiro JA, Gilbert J, Díaz I. 1994. Determination of neutral lipids from subcutaneous fat of cured ham by capillary gas chromatography and liquid chromatography. J. Chromatogr. A 667, 225-233. http://dx.doi. org/10.1016/0021-9673(94)89071-4.

Gómez M, Lorenzo JM. 2013. Effect of fat level on physicochemical, volatile compounds and sensory characteristics of dry-ripened "chorizo" from Celta pig breed. Meat Sci. 95, 658-666. http://dx.doi.org/10.1016/j.meatsci.2013.06.005.

González-Fernández C, Santos EM, Rovira J, Jaime I. 2006. The effect of sugar concentration and starter culture on instrumental and sensory textural properties of chorizo Spanish dry-cured sausage. Meat Sci. 74, 467-475. http:// dx.doi.org/10.1016/j.meatsci.2006.04.019.

ISO. 1991. Method of investigating sensitivity of taste, ISO 3972:1991. International Organization for Standardization. Genève, Switzerland

ISO. 1994. Methodology. Texture profile, ISO 11036:1994. International Organization for Standardization. Genève, Switzerland.

ISO. 1997. Determination of moisture content, ISO 1442:1997 standard, in International Organization for Standardization (Ed.) International standards meat and meat products, Switzerland.

ISO. 2006. Methodology. Initiation and training of assessors in the detection and recognition of odours, ISO 5496:2006. International Organization for Standardization. Genève, Switzerland.

ISO. 2007. General guidance for the design of test rooms, ISO 8589:2007. International Organization for Standardization. Genève, Switzerland.

ISO. 2012. Sensory analysis - General guidance for the selection, training and monitoring of assessors - Part 1: Selected assessors, ISO 8586:2012. International Organization for Standardization. Genève, Switzerland.

Liaros NG, Katsanidis E, Bloukas JG. 2009. Effect of the ripening time under vacuum and packaging film permeability on processing and quality characteristics of low-fat fermented sausages. Meat Sci. 83, 589-598. http://dx.doi.org/10.1016/ j.meatsci.2009.07.006.

Lorenzo JM. 2014. Influence of the type of fiber coating and extraction time on foal dry-cured loin volatile compounds extracted by solid-phase microextraction (SPME). Meat Sci. 96, 179-186. http://dx.doi.org/10.1016/j.meatsci.2013. 06.017 .

Lorenzo JM, Franco D, Carballo J 2014 Effect of the inclusion of chestnut in the finishing diet on volatile compounds during the manufacture of dry-cured "Lacón" from Celta pig breed. Meat Sci. 96, 211-223. http://dx.doi.org/10.1016/ j.meatsci.2013.07.007.

Lorenzo JM, Franco D. 2012. Fat effect on physico-chemical, microbial and textural changes through the manufactured of dry-cured foal sausage: lipolysis, proteolysis and sensory properties. Meat Sci. 92, 704-714. http://dx.doi. org/10.1016/j.meatsci.2012.06.026.

Lorenzo JM, Montes R, Purriños L, Cobas N, Franco D. 2012a. Fatty acid composition of Celta pig breed as influenced by sex and location of fat in the carcass. J. Sci. Food Agr. 92, 1311-1317. http://dx.doi.org/10.1002/jsfa.4702.

Lorenzo JM, Montes R, Purriños L, Franco D. 2012b. Effect of pork fat addition on the volatile compounds of foal dry-cured sausage. Meat Sci. 91, 506-512. http://dx.doi. org/10.1016/j.meatsci.2012.03.006.

Lorenzo JM, Temperán S, Bermúdez R, Cobas N, Purriños L. 2012c. Changes in physico-chemical, microbiological, textural and sensory attributes during ripening of drycured foal salchichón. Meat Sci. 90, 194-198. http://dx.doi. org/10.1016/j.meatsci.2011.06.025.

Lorenzo JM, Bedia M, Bañon S. 2013. Relationship between flavour deterioration and the volatile compound profile of semi-ripened sausage. Meat Sci. 93, 614-620. http://dx.doi. org/10.1016/j.meatsci.2012.11.006.

Lücke FK. 1994. Fermented meat products. Food Res. Int. 27, 299-307. http://dx.doi.org/10.1016/0963-9969(94)90098-1.

Mendoza E, García ML, Casas C, Selgas MD. 2001. Inulin as fat substitute in low fat, dry fermented sausages. Meat Sci. 57, 387-393. http://dx.doi.org/10.1016/S03091740(00)00116-9.

Muguerza E, Ansorena D, Bloukas JG, Astiasarán I. 2003. Effect of fat level and partial replacement of pork backfat with olive oil on the lipid oxidation and volatile compounds of Greek dry fermented sausages. J. Food Sci. 68, 1531-1536. http://dx.doi.org/10.1111/j.1365-2621.2003. tb09679.x.

Muguerza E, Gimeno O, Ansorena D, Bloukas JG, Astiasarán I. 2001. Effect of replacing pork backfat with pre-emulsified olive oil on lipid fraction and sensory quality of Chorizo de Pamplona - A traditional Spanish fermented sausage. Meat Sci. 59, 251-258. http://dx.doi.org/10.1016/ S0309-1740(01)00075-4

Muriel E, Antequera T, Petrón MJ, Andrés AI, Ruiz J. 2004. Volatile compounds in Iberian dry-cured loin. Meat Sci. 68, 391-400. http://dx.doi.org/10.1016/j.meatsci.2004.04.006.

Navarro JL, Nadal M, Izquierdo L, Flores J. 1997. Lipolysis in dry cured sausages as affected by processing conditions. Meat Sci. 45, 161-168. http://dx.doi.org/10.1016/S03091740(96)00118-0.

Navarro JL, Nadal MI, Nieto P, Flores J. 2001. Effect of nitrate and nitrite curing salts on the generation and oxidation of fatty acids in non-fermented sausages. Eur. Food Res. Technol. 212, 421-425. http://dx.doi.org/10.1007/ s002170000275.

Olivares A, Navarro JL, Flores M. 2011. Effect of fat content on aroma generation during processing of dry fermented sausages. Meat Sci. 87, 264-273. http://dx.doi.org/10.1016/ j.meatsci.2010.10.021.

Olivares A, Navarro JL, Salvador A, Flores M. 2010 Sensory acceptability of slow fermented sausages based on fat content and ripening time. Meat Sci. 86, 251-257. http:// dx.doi.org/10.1016/j.meatsci.2010.04.005.

Pérez-Álvarez JA, Sayes-Barbare ME, Fernández-López J, Aranda-Catala V. 1999. Physicochemical characteristics of Spanish type dry-cured sausage. Food Res. Int. 32, 599-607. $\mathrm{http}: / / \mathrm{dx}$.doi.org/10.1016/S0963-9969(99)00104-0.

Purriños L, Carballo J, Lorenzo JM. 2013. The Influence of Debaryomyces hansenii, Candida deformans and Candida zeylanoides on the aroma formation of dry-cured "lacón". Meat Sci. 93, 344-350. http://dx.doi.org/10.1016/j.meatsci. 2012.09.015.

Purriños L, Franco D, Carballo J, Lorenzo JM. 2012. Influence of the salting time on volatile compounds during the manufacture of dry-cured pork shoulder "Lacón". Meat Sci.92, 627-634. http://dx.doi.org/10.1016/j.meatsci.2012.06.010.

Purriños L, Bermúdez R, Franco D, Carballo J, Lorenzo JM. 2011. Development of volatile compounds during the manufacture of dry-cured "lacón" a Spanish traditional meat product. J. Food Sci. 76, C89-C97. http://dx.doi. org/10.1111/j.1750-3841.2010.01955.x.

Ramírez R, Cava R. 2007. Volatile profiles of dry-cured meat products from three different Iberian X Duroc genotypes. J. Agr. Food Chem. 55, 1923-1931. http://dx.doi.org/10.1021/ jf0628101. 
Roberts DD, Pollien P, Antille N, Lindinger C, Yeretzian C. 2003. Comparison of nosespace, headspace, and sensory intensity ratings for the evaluation of flavor absorption by fat. J. Agric. Food Chem. 51, 3636-3642. http://dx.doi. org/10.1021/jf026230+

Ruiz J, Ventanas J, Cava R, Andrés A, García C. 1999. Volatile compounds of dry-cured Iberian ham as affected by the length of the curing process. Meat Sci. 52, 19-27. http:// dx.doi.org/10.1016/S0309-1740(98)00144-2.

Salazar P, García ML, Selgas MD. 2009. Short-chain fructooligosaccharides as potential functional ingredient in dry fermented sausages with different fat levels. Int J. Food Sci. Technol. 44, 1100-1107. http://dx.doi.org/10.1111/ j.1365-2621.2009.01923.x.
Soyer A, Ertas AH, Üzümcüoğlu Ü. 2005. Effect of processing conditions on the quality of naturally fermented Turkish sausages (sucuks). Meat Sci. 69, 135-141. http://dx.doi. org/10.1016/j.meatsci.2004.06.015.

Spaziani M, Del Torre M, Stecchini ML. 2009. Changes of physicochemical, microbiological, and textural properties during ripening of Italian low-acid sausages. Proteolysis, sensory and volatile profiles. Meat Sci. 81, 77-85. http:// dx.doi.org/10.1016/j.meatsci.2008.06.017.

Vyncke W. 1975. Evaluation of the direct thiobarbituric acid extraction method for determining oxidative rancidity in mackerel (Scomber scombrus L.). Fett. Wiss. Technol. 77, 239-240. 